\title{
Genç Basketbolcularda Anjiotensin Dönüştürücü Enzim (ACE I/D) ve Alfa- Aktinin-3 (ACTN3 R577X) Gen Polimorfizmlerinin Belirlenmesi için Pilot Bir Çalışma
} A Pilot Study for the Determination of Angiotensin I-Converting Enzyme (ACE I/D) and Alpha-Actinin-3 (ACTN3 R577X) Polymorphisms in Young Basketball Players

\section{Araştırma Makalesi}

1,2Korkut ULUCAN, ${ }^{2}$ Nurdan ÇAM, 'Canan SERCAN, ${ }^{3}$ Berkay AKBAŞ, ${ }^{3}$ Fırat UYUMAZ, ${ }^{3}$ Sevim YALCIN

1Marmara Üniversitesi, Diş Hekimliği Fakültesi, Tıbbi Biyoloji ve Genetik Bölümü, İstanbul, Türkiye 2 Üsküdar Üniversitesi, Mühendislik ve Doğa Bilimleri Fakültesi, Moleküler Biyoloji ve Genetik Bölümü, i̇stanbul, Türkiye 3Doğa Koleji Bostancı Kampüsü, Biyoloji Bölümü, İstanbul, Türkiye

\section{öz}

$\overline{\text { ABSTRACT }}$
distribution of alpha- actinin-3 (ACTN3) R577X and angiotensin converting enzyme ( $A C E)$ I/D polymorphisms in a total of 24 elite young basketball players, 17 female and 7 male. DNA samples from the players were isolated from buccal cells by using commercial DNA isolation kit. Genotyping process for ACTN3 was carried out by polymerase chain reaction- restriction fragment length polymorphism (PCR-RFLP), and PCR for ACE. 16 of the examined players had RR, 6 had $R X$ and 2 of the players had $X X$ genotype for the ACTN3 R577X polymorphism. When we examine them according to genders, 11 of the $17 \mathrm{fe}$ - 
ise 5 ve 2 oyuncu sırasıyla RR ve RX genotiplerinde bulunmuştur. ACE için, 11 oyuncu DD, 12 oyuncu ID ve sadece 1 oyuncu II genotipindedir. Cinsiyetlerine göre incelediğimizde kızlarda 7 oyuncu DD, 10 oyuncu ID genotipinde, erkelerde ise 4 oyuncu DD, 2 oyuncu ID ve yalnız 1 oyuncu II genotipindedir. ACTN3 R alleli kızlarda 26, erkeklerde 12, X alleli ise kızlarda 8, erkeklerde 2 olarak bulunmuştur. ACE genotipi için D alleli kızlarda 24, erkeklerde 10, I alleli ise kızlarda 10 ve erkeklerde 4 olarak saptanmıştır. Bu çalışmamizda ACTN3 DD genotipinin ve R alleinin, ACE polimorfizminde ise ID genotipinin ve $D$ alleinin çalışma grubunda daha baskın olduğu görülmüştür. Bu oyuncu grubunda ilk kez gerçekleştirilen bu pilot çalışma ile bundan sonra daha yüksek veri kaynaklı çalışmalara ışık tutacağı inancındayız.

\section{Anahtar Kelimeler}

Basketbol, polimorfizm, ACTN3, ACE, Spor male players had RR, 4 had $R X$ and 2 had $X X$ genotypes. For males, 5 and 2 players had RR and RX genotypes, respectively. For $A C E, 11$ players were DD, 12 were ID and only one of them was II. 7 had DD and 10 had ID genotypes for the females; 4 had DD, 2 had ID and only one had II genotype. R allele of the ACTN3 was counted as 26 in females and 12 in males, whereas $X$ allele was 8 in females and 2 in males. For ACE, D allele was counted as 24 in females and 10 in males, whereas I allele counted as 10 in females and 4 in males. Our results showed that ACTN3 RR genotype and $\mathrm{R}$ allele,ACE ID geotype and $D$ allele dominated in our cohort. We hope that this first pilot study carried out in basketball players will guide further studies with extended numbers of players.

\section{Key Words}

Basketball, polymorphism, ACTN3, ACE, sport

\section{Gíriş}

Sportif performans, bireyin doğuştan gelen genetik yapısı ve sonradan kazandığı çevresel faktörlerin bileşimi olarak oluştuğuna inanılmaktadır. Dayanıklılık, patlayıcı kuvvet, güç, kas koordinasyonu, psikolojik isteklilik ve motivasyon gibi kişisel özelliklerin, disiplinli ve programlı spor hayatının yanında sporcuların genetik altyapıları ile belirlendiği bilinmektedir (Ulucan, 2015). Spor genetiği, bireylerin atletik performansına, sakatlanma risklerine ve beslenmelerine etki eden genetik varyantlar üzerine odaklanır. Bu özelliklere etki ettiği düşünülen genetik varyasyonların belirlenmesi, sporcu adaylarının doğru sporu seçmeleri veya sporcuların daha verimli antreman programları oluşturabilmelerine olanak sağlayacaktır. Sadece bireysel sporlarda değil, takım sporlarında da sporcuların görevlerini yerine getirmesi, takım organizasyonu için önem teşkil etmektedir. Bu yüzden sporcuların genetik yapılarına uygun beslenme ve egzersiz programları ile daha kısa sürede optimal başarı sağlanacağı şüphesizdir. Bu amaçla sporcularda genetik yapının incelenmesi gerek bireylere, gerekse spor kulüplerine önemli katkılar

sağlayacaktır. Aynı zamanda egzersiz, spor ve beslenme ile ilgili genomik veritabanlarının oluşturulması, sporla uğraşan bilim insanları için doğru yönlendirilme yapılmasında faydalı olacaktır.

Spor genetiği ile ilgili ilk önemli çalışmalar anjiotensin I dönüştürücü enzim $(A C E)$ geni ile başlamıştır (Montgomery ve diğ., 1998). ACE, 17q23 konumunda bulunur ve ürünü $A C E$ proteini, gendeki bir varyasyondan dolayı dokularda farklı düzeylerdedir. $A C E^{\prime}$ nin 16. intronunda bir tekrar dizisinin bulunup bulunmamasına göre genin kısa (delesyonlu, D) ve uzun (insersiyonlu, I) alleleri bulunmaktadır (Ulucan ve Göle, 2014). DD genotipli bireyler, ID ve II'lerden daha yüksek doku ve serum ACE konsantrasyonlarına sahiptir (Jones ve diğ., 2002). Önceki çalışmalarda kısa mesafe koşu, yüzme, yüksek atlama veya disk atma gibi patlayıcı güç odaklı sporlarda DD genotipinin yatkınlık sağladığı belirtilmiştir (Jones ve diğ., 2002; Costa ve diğ., 2009). Öte yandan, daha düşük ACE serum konsantrasyonuna sahip genotip II genotipli bireylerin ise orta ve uzun mesafe koşu, uzun mesafeli yürüme, rüzgar sörfü ve kürek gibi dayanıklılıkla ilgili dis- 
iplinlere daha yatkın olduğu belirtilmiştir (Montgomery ve diğ.,1998; Cieszczyk ve diğ., 2009; Ulucan ve Göle, 2014).

Alfa- aktinin geni (ACTN3, MIM102574) sportif performansla ilişkilendirilmiş iskelet kasına ait ilk yapısal gendir (Yang ve diğ., 2003). Genin ürünü, ACTN3 proteini, sarkomerlerin $Z$ çizgilerinde lokalizedir ve aktinlerin $Z$ çizgisine daha sıkı bağlamakla görevlidirler (Holdys ve diğ., 2011). North ve diğ. (1999), ACTN3' ün 16. ekzonunun 577. amino asidi kodlayan kodonunda meydana gelen varyasyonun (R577X; dbSNP rs1815739), arjinin amino asidinin $(\mathrm{R})$ stop kodonuna $(\mathrm{X})$ dönüştürdüğünü bildirmişlerdir. Bu dönüşüm, proteinin normal formundan daha kısa bir protein oluşumuna neden olmaktadır. Günümüze kadar yapılan çalışmalar, 577R alleli ve RR genotipinin patlayıcı güç ve sprinter odaklı sportif performansa (Cięszczyk ve diğ., 2011), 577X alleli ve XX genotipinin dayanıklılık odaklı sportif performansa yatkınlık sağladığı konusunda yoğunlaşmıştır. (Niemi ve diğ., 2005; Papadimitriou ve diğ., 2008; Ulucan ve diğ., 2013).

Basketbol hem sporcuların dayanıklılık göstermeleri, hem de özellikle depar ve sıçrama anlarında gösterdikleri patlayıcı güç anlamında fenotip olarak karma bir spor türüdür. Bu yüzden genotip olarak belirli bir varyant dağılımını beklemek güçtür. Genetik olarak incelendiğinde, basketbolcular da patlayıcı güç fenotipine uygun olan genetik varyantların ve dayanıkııık fenotipine uygun genetik varyantların karışık olarak bulunması beklenmektedir. Bu yüzden bu spor dalı ile ilgili net bir hipotez konulamadığından, bu spor branşı ile ilgili sporcular üzerine yapıımış çok fazla genetik çalışma bulunmamaktadır. Bu çalışmamızda farklı populasyon ve spor branşlarında sportif performans ile ilişkilendirilmiş ACE I/D ve ACTN3 R577X polimorfizmlerinin genç basketbol oyuncularında dağııımını belirlemeyi amaçladık.

\section{YÖNTEM}

\section{Çalışma Grubu}

Çalışmamıza Doğa Koleji Basketbol takım oyuncularından 17 kız, 7 erkek olmak üzere toplam 24 lisanslı basketbol oyuncusu katılmıştır. Tüm oyuncular hem okul hem de farkı kulüp takımlarında lisanslı olarak basketbol hayatlarına devam etmektedirler. Çalışma protokolü, Helsinki Bildirgesi'ne uygun olarak yürütülmüş ve çalışma, Üsküdar Üniversitesi Etik Kurul Komitesi tarafından onaylanmıştır. Çalışmaya katılma koşulları ve çalışma planını anlatan gönüllü onay formu, oyuncular 18 yaşının altında olduklarından velilerine veya bildirdikleri yetkili bireylere imzalatılarak onaylatılmıştır.

\section{Genotipleme}

Çalışmamızda genotip analizleri için DNA eldesi, ağız içi epitel hücrelerden sağlanmıştır. İzolasyon işlemi, ticari olarak sağlanan "Buccal Amp $^{T M}$ DNA Extraction Kit, Epicentre, USA" ile gerçekleştirilmiştir. Elde edilen DNA örnekleri, ilgili genlerin analizlerinin tamamlanmasına kadar $-20{ }^{\circ} \mathrm{C}$ de saklanmıştır.

ACTN3 R577X polimorfizminin belirlenmesi polimeraz zincir reaksiyonu ve restriksiyon enzim kesimi metodu (PCR- RFLP) ile gerçekleştirilmiştir. ilıili bölge, 5'-CTG TTG CCT GTG GTA AGT GGG-3' ve 5'-TGG TCA CAG TAT GCA GGA GGG-3' primerleri ile daha önce belirtilen koşullarda çoğaltılmış (Ulucan ve diğ., 2014), elde edilen amplikonlar Ddel restriksiyon enzimi ile kesilmiştir. Genotipleme işlemi, kesilen amplikonların poliakrilamid jel elektroforezi ile tamamlanmıştır (Şekil 1).

ACE I/D genotiplemesi ise PCR yöntemi ile gerçekleştirilmiştir. $A C E^{\prime}$ nin ilgili bölgesi 5'-CTG

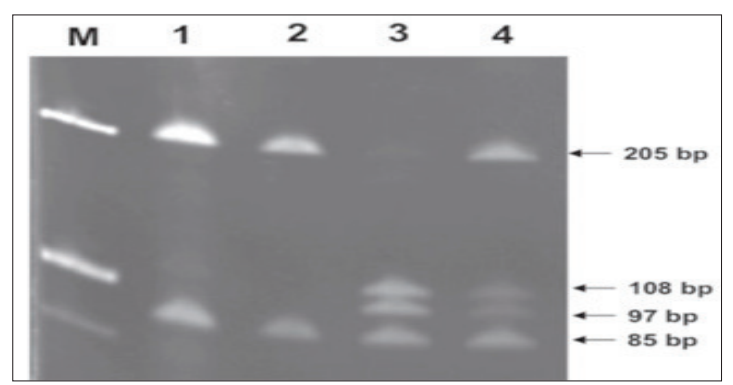

Şekil 1. ACTN3 amplifikasyon örneklerinin Ddel restriksiyon enzim kesimi poliakrilamid jel elektroforez görüntüleri. M: Marker, 100 bp'lik, 1.2: RR genotipli bireyler. 3 nolu birey $\mathrm{XX}, 4$ nolu birey $\mathrm{RX}$. 


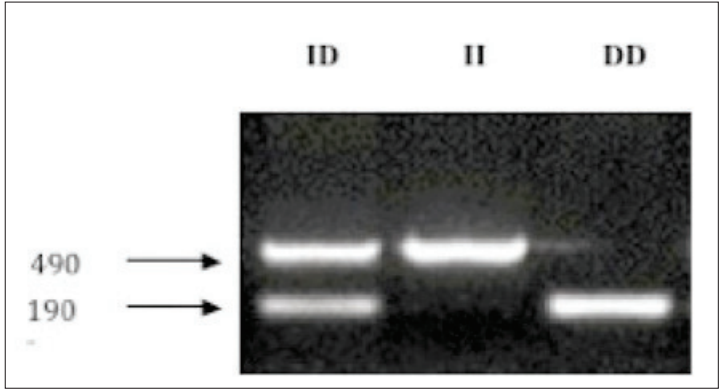

Şekil 2. ACE genotipinin belirlenmesi. Amplifikasyon ürünlerinin \%2'lik agaroz elektroforez görüntüsü.

GAG ACC ACT CCC ATC CTT TCT-3' ve 5'-GAT GTG GCC ATC ACA TTC GTC AGT-3' primerleri ile daha önce belirtilen koşullarda amplifiye edilmiş (Güney ve diğ., 2013), genotipleme işlemi agaroz elektroforezi ile tamamlanmıştır (Şekil 2).

\section{İstatistiksel Analizler}

Analiz edilen her iki gen için genotip ve alel frekans dağılımları ve yüzdeleri hesaplanmıştır.

\section{BULGULAR}

Çalışmamıza 24 genç basketbolcu katılmıştır, katılımcıların 17'si kız (\%71), 7'si ise erkek (\%29) basketbolcudan oluşmuştur. Her iki gen için genotip ve allelik dağılımlar sırasıyla Tablo 1 ve
Tablo 2'de özetlenmiştir.

ACTN3 analizi sonuçlarına göre 16 oyuncu RR, 6'sı RX ve 2'sinde ise XX genotipindedir. Cinsiyete göre ayırdığımızda 17 kız basketbolcunun 11'i RR, 4'ü RX ve 2'si XX; erkeklerin ise 5'i RR, 2'si RX genotiplerine sahiptir. Çalışma grubundaki erkeklerde $X X$ genotipi bulunmamıştır.

$A C E$ sonuçlarına göre toplamda 11 oyuncu DD, 12'si ID ve 1 tanesi II genotipindedir. Cinsiyetlerine göre baktığımızda kız oyuncuların 7'si DD, 10'u ID; erkek oyuncuların ise 4'ü DD, 2'si ID ve 1 tanesi de II genotiplerine sahiptir. KIz oyuncularda II genotipine rastlanmamıştır.

Allelik dağılımlar incelendiğinde ACTN3'ün $\mathrm{R}$ alleli çalışma grubunda $38, \mathrm{X}$ alleli ise 10 olarak bulunmuştur. ACE için D alleli 34, I alleli ise 14 olarak bulunmuştur. Cinsiyetlerine göre dağılımlarda kızlarda ACTN3 $\mathrm{R}$ alleli 26, $\mathrm{X}$ alleli ise 8, ACE D alleli 24, I alleli ise 10 olarak bulunmuştur. Aynı alleller erkek oyuncularda ACTN3 $\mathrm{R}$ alleli $12, \mathrm{X}$ alleli ise 2, ACE D alleli 10, I alleli ise 4 olarak bulunmuştur.

incelenen polimorfizmlerin sporculardaki combine dağılımlarına göre 7 oyuncu RR+DD genotipnde, 8 oyuncu RR+ID, 1 oyuncu RR+II

Tablo 1. Analiz edilen ACTN3 ve ACE polimorfizmlerinin basketbolculardaki dağılımı

\begin{tabular}{c|c|c|c|c|c|c}
\hline & \multicolumn{3}{|c|}{ ACTN3 } & XX & DD & ID \\
\hline & RR & RX & ICE & II \\
\hline Kız (Yüzde) & $11(\% 46)$ & $4(\% 17)$ & $2(\% 8)$ & $7(\% 29)$ & $10(\% 42)$ & $2(\% 8)$ \\
\hline Erkek (Yüzde) & $5(\% 21)$ & $2(\% 8)$ & - & $4(\% 17)$ & $1(\% 4)$ \\
\hline Toplam & $16(\% 67)$ & $6(\% 25)$ & $2(\% 8)$ & $11(\% 46)$ & $12(\% 50)$ & $1(\% 4)$ \\
\hline
\end{tabular}

Tablo 2. Incelenen ACTN3 ve ACE allellerinin basketbolcularda dağılımı

\begin{tabular}{c|c|c|c|c}
\hline & \multicolumn{2}{|c|}{ ACTN3 } & ACE & D \\
\hline & $\mathrm{R}$ & $\mathrm{X}$ & $24(\% 50)$ & $10(\% 21)$ \\
\hline Kız (Yüzde) & $26(\% 54)$ & $8(\% 17)$ & $10(\% 21)$ & $4(\% 8)$ \\
\hline Erkek (Yüzde) & $12(\% 25)$ & $2(\% 4)$ & $34(\% 71)$ & $14(\% 29)$ \\
\hline
\end{tabular}


Tablo 3. ACTN3 ve ACE polimorfizmlerinin sporcularda ki kombine dağılımı

\begin{tabular}{c|c|c|c}
\hline \multirow{2}{*}{$\begin{array}{c}\text { ACTN3 } \\
\text { (Genotip sayısı) }\end{array}$} & DD & ID & II \\
\cline { 2 - 4 } & 7 & 8 & 1 \\
\hline RR & 3 & 3 & - \\
\hline RX & 1 & 1 & - \\
\hline
\end{tabular}

olarak bulunmuştur. 3'er oyuncunun genotipleri sırasıyla $R X+D D$ ve $R X+I D$ 'tir. Sadece 1'er oyuncu sırasıyla $X X+D D$ ve $X X+I D$ genotipinde bulunmuştur. Bu bulgular Tablo $3^{\prime}$ te özetlenmiştir.

\section{TARTIŞMA}

Spor genetiği alanında son yıllarda yapılan çalışmalar oyuncuların performansının belirlenmesinde genetik faktörlerin önemini göstermiştir. Sporcular için hazırlanabilecek genomik veritabanları, bireylerin ne tip spor branşına uygun olduklarını belirleme de spor bilimcilere yararlı veriler sağlayabilecektir (Ulucan ve diğ., 2015).

Çalışma grubumuzda ACTN3 R577X polimorfizmi incelendiğinde güç ve sprint spor aktiviteleri ile ilişkili olan $\mathrm{R}$ alleli ile $\mathrm{RR}$ ve $\mathrm{RX}$ genotipleri, hem erkek hem de kız oyuncularda daha yüksek bulunmuştur. Bu allel, çizgili kasların daha hızlı kasılmasına neden olduğu için kısa süreli kuvvet ve sprint aktvitesine yatkınlık sağlamaktadır. Benzer bir çalışmada, Garatachea ve diğ. (2014) İspanyol basketbolcularda RR genotipini \%37, RX genotipini ise \%42 olarak bulmuşlardır, iki genotipin çalışma grubunda ki oranı \%92 olarak bildirilmiştir. Bizim çalışmamızda da RR genotipli oyuncular $\% 67$, RX genotipli oyuncular \%25 olarak bulunmuş, toplam olarak RR ve RX genotiplerinin, yani en az bir R alleli içeren bireylerin oranı \%92'dir. Bu açıdan çalışmamız Garatachea ve diğ. (2014) çalışmasına benzerlik göstermektedir.Sessa ve diğ. (2011) içlerinde basketbol oyuncularınında bulunduğu sporcu grubunda ACTN3 geninde ki bu yaygın polimorfizmin sprint/güç odaklı spor- cular için önemli olduğunu, ancak basketbolcularda diğer sprinter özellikteki sporcular ile kıyasladığında istatistiksel olarak anlam teşkil etmediğini bildirmişlerdir. ACTN3 R577X polimorfizmi ve basketbolcular ile ilişkili literatürde fazla çalışma bulunmadığından dolayı çok fazla kıyaslama yapamamaktayız. Ülkemizde yapılan çalışmalarda Günel ve diğ. (2014) 37 farklı disipllinlerden oluşan elit atletlerde yaptıkları çalışmada XX ve RX genotipini sırasıyla \%35,14 ve $\% 54,05$ olarak bildirmişlerdir. Bu bireylerde $X$ allelinin daha yüksek olması, dayanıklılık gerektiren sporlarda bu allelin yatkınlık sağlaması olarak açıklamışlardır. Ulucan ve diğ. (2015) profesyonel erkek futbolcular üzerine yaptıkları araştırmada RR ve RX genotiplerini XX genotipine kıyasla daha baskın olarak belirtmişlerdir. Şanlısoy ve diğ. (2011) aralarında basketbol, atletizm, judo, güreş, tekvando, bisiklet, futbol ve tenis sporcuları bulunan 105 Ege yöresi elit sporcu da aynı genetik bölgenin analizini yapmışlar, RR ve RX genotipli sporcuların sedenter bireylere göre daha yüksek olduğunu bildirmişlerdir. Aynı yazarlar ACTN3'ün sporcularda sprinter ve dayanıklılık özelliklerinin belirlenmesinde önemli bir biyolojik marker olduğunu bildirmişlerdir. Bizim sonuçlarımız da sporcularda RR ve RX genotiplerinin, $X X$ genotipine göre daha baskın olması açısından Şanlısoy ve diğ. (2011) sonuçları ile uyum göstermektedir. Benzer bir çalışmayı Yamak ve diğ. (2015) içlerinde futbol, basketbol, atletizm, voleybol, hentbol, judo, güreş, tekvando ve Amerikan futbolu bulunan yaklaşık 150 sporcu da gerçekleştirmiş, sporcu grubunda RR ve RX genotiplerini sırasıyla \%30,6 
ve $\% 47,3$ olarak bildirmişlerdir. Grubumuzun yaptığı bir çalışmada da 20 genç sprinter özellikli sporcunun ACTN3 genotipleri analiz edilmiş, $50 \mathrm{~m}$ koşu mesafesi süreleri ölçülerek sedenter bireylerle karşılaştırılmıştır. RR ve RX genotipli sporcuların aynı genotipli sedenterlere göre kıyaslandığında istatistiksel olarak daha başarılı oldukları bulunmuştur (Ulucan ve diğ., 2014).

$A C E$ genotipine göre çalışma grubuna baktığımızda kızlarda ID genotipi, erkek basketbolcularda ise DD genotipinin daha fazla olduğu görülmektedir. DD genotipinin ve D allelinin kuvvet ve sprinter sporcularda daha fazla bulunduğu ve bu tip sporlara yatkınlık sağladığı bilmektedir. Oh ve diğ. (2007) içinde basketbol oyuncularınında bulunduğu 139 Kore'li sporcularda ACE I/D polimorfizmini sedenter bireylerle karşılaştırmış, sadece uzun mesafe koşucularında II genotipinin ve I allelinin daha baskın olduğunu bildirmişlerdir. Günel ve diğ. (2014) 37 elit atlette yaptıkları çalışmalarında bizim sonuçlara benzer bulgulara ulaşmışlar, DD ve ID gruplarını sırasıyla \%51,35 ve \%40,54 olarak bulmuşlardır. Sessa ve diğ. (2011) içlerinde basketbol oyuncularınında bulunduğu 53 oyuncunun ACE I/D polimorfizminin sedenter bireyler ile karşılaştırıldığında istatistiksel olarak bir fark bulunmadığını bildirmişlerdir. Ulucan ve diğ. (2015) profesyonel erkek futbolcular üzerinde yaptıkları çalışma da DD ve ID genotipleri ile $D$ allelini futbolcularda yüzdesel olarak daha fazla olduğunu belirtmişlerdir.

Çalışma grubumuzdaki gen polimorfizm bileşimlerine göre ACTN3 RR ve ACE ID kombinasyonu en fazla bireye sahiptir. Aynı şekilde 7 oyuncu ise RR + DD genotipindedir. Günel ve diğ. (2014) yaptığı çalışmada RX + ID ve RX + DD genotipleri enfazla sayıda bulunmuştur. Bizim çalışmamızda en fazla sayıda bulunan RR + ID genotipi Günel ve ark. (2014) yaptığı çalışma da sadece 1 oyuncuda, RR + DD genotip kombinasyonu ise sadece 3 oyuncuda bulunmuştur.

Çalışmamızda ki en büyük limitasyon çalışma grubumuzdaki denek sayısının azlığıdır. Bu tip allel analiz çalışmaları daha yüksek sayılarda yapıldığı takdirde amacına daha net ulaşmış olmaktadır. Çalışma grubunun homojenizasyonunun sağlanması amacıyla biz sadece bir basketbol takımı oyuncuları ile çalışma planladık. Erkek basketbolcularımız çalışmaya tam takım olarak katılmayı kabul etmediklerinden tüm takımı çalışmaya almamak yerine sadece katılmayı kabul edenleri çalışmamıza dahil ettik. Az sayıda denek olmasına rağmen bu tip çalışmanın ilk kez bu yaş grubunda ki basketbolcularda yapılması daha sonra yapılacak çalışmalara öncü olacağı kanısındayız.

Çalışmamızda kontrol grubu, yani sedenter bireyler ile bir karşılaştırılma yapılmamıştır. Bunun nedeni, analiz edilen genetik parametrelerin sportif faaliyetlere olan etkilerinin yapılan çalışmalar ile ortaya konmasıdır. Her ne kadar bu çalışmamızda analiz edilen genetik varyantlar ve atletik performans ilişkisi bugüne kadar yapılan çalışmalarda her zaman aynı sonuçları vermese de çoğunlukta birbirlerini destekleyen sonuçlar bildirilmiştir. Ancak bu tip analizler Türk sporcular üzerinde yeteri kadar yapılmamış ve literatürde bu genetik parametrelerin Türk sporculardaki dağılımları hakkında yeteri kadar bilgimiz bulunmamaktadır. Çalışmada bu yüzden kontrol grubu kullanılmamış, çalışma dizaynı olarakta istatistiksel analiz yapılmamıştır. Aynı zamanda kontrol grupları, genelde biyoinformatiği tam olarak anlaşılamamış analizlerin etkinliğini ölçmek için kullanıldığından, biz bu çalışmamızda sedenter bireyler ile istatistiksel analiz yapmayı planlamadık. Ancak daha geniş denek sayılı ve farklı spor branşlarından sporcuların olduğu çalışmalar planlamaktayız. Böylece ilgili genetik parametrelerin sporcuların başarısına olan etkilerini daha net anlayabileceğimizi düşünmekteyiz.

\section{SONUÇ ve ÖNERILER}

Sonuç olarak ACE ve ACTN3 sportif faaliyetlere genetik yatkınlık, predispozisyon, çalışmalarında önemli rolleri olan genlerdir. Bu çalışmamızda ilk defa Türkiye'de basketbol oynayan, genç basketbolcularda ilgili genetik 
biyomarkerların analizleri gerçekleştirilmiştir. Ancak ilgili genetik bölgelerin sportif performansa etkileri ile daha anlamlı sonuçlar verebilmesi için, daha fazla sayıda, ve farklı sportif branşlarda sporcu analizlerinin gerçekleştirilmesi gerekmektedir. Bu çalışmanın daha sonra yapılacak olan çalışmalara kaynak ve yol gösterecek pilot çalışma olarak önemli olduğunu düşünmekteyiz.

\author{
Yazıșma Adresi (Corresponding Address): \\ Doç.Dr. Korkut ULUCAN \\ Üsküdar Üniversitesi, Moleküler Biyoloji ve Genetik \\ Bölümü, Haluk Türksoy Sok. No:14, Altunizade, \\ Üsküdar, İstanbul, 34662 \\ E-posta: korkutulucan@hotmail.com \\ Telefon No: +90 (216) 40022 22, \\ +905326921922 \\ Faks No: +90 2164741256
}

\section{K AY N A KL AR}

1. Ulucan K. (2015). Need For Sports Genetics. Journal of Investigative Genomics, 2(2): 00021.

2. Montgomery HE, Marshall R, Hemingway H. (1998). Human gene for physical performance. Nature 393(6682), 221-222.

3. Ulucan K, Göle S. (2014). ACE I/D Polymorphism Determination in Turkish Elite Wind-surfers. Sport Science Review, 23(1-2), 79-84.

4. Jones A, Montgomery HE, Woods DR. (2002). Human performance: a role for the ACE genotype?. Exercise and Sport Science Reviews, 30(4), 184-190.

5. Costa AM, Silva AJ, Garrido ND. (2009). Association between ACE $D$ allele and elite short distance swimming. European Journal of Applied Physiology, 106(6), 785-790.

6. Cieszczyk P, Krupecki K, Maciejewska A. (2009). The angiotensin converting enzyme gene I/D polymorphism in Polish rowers. International Journal Sports Medicine 30(8), 624-627.

7. Yang N, Macarthur DG, Gulbin JP. (2003). ACTN3 genotype is associated with human elite athletic performance. American Journal of Human Genetics, 73(7), 627-631.

8. Holdys J, Stanislawski D, Krysciak J. (2011) Polymorphism of the -ACTN3 gene in individuals practising different sports disciplines. Biology of Sport, 28(1), 101-106.

9. North KN, Yang N, Wattanasirichaigoon D, Mills-M, Easteal S, Beggs AH. (1999). A common nonsense mutation results in alpha-actinin-3 deficiency in the general population. Nature Genetics, 21(4), 353-354.

10. Niemi AK, Majamaa K. (2005). Mitochondrial DNA and ACTN3 genotypes in Finnish elite endurance and sprint athletes. European Journal of Human Genetics, 13(8), 965-969.

11. Papadimitriou ID, Papadopoulos C, Kouvatsi A. (2008). The ACTN3 gene in elite Greek track and field athletes. International Journal of Sports Medicine, 29(4), 352-355.

12. Ulucan K, Göle S, Altindas N, Güney Al. (2013). Preliminary Findings of $\alpha$-Actinin-3 Gene Distribution in Elite Turkish Wind Surfers. Balkan Journal of Medical Genetics, 16(1), $69-72$.

13. Ulucan K, Bayyurt GM, Konuk M, Güney Al. (2014). Effect of alpha-actinin-3 gene on trained and untrained
Turkish middle-school children's sprinting performance: a pilot study. Biological Rhythm Research, 45(4), 509-514.

14. Güney Al, Ergec $D$, Kirac $D$, Ozturhan $H$, Caner M, Koc G, Kaspar C, Ulucan K, Agirbasli M. (2013). Effects of ACE polymorphisms and other risk factors on the severity of coronary artery disease. Genetics and Molecular Research, 12(4), 6895-6906.

15. Ulucan K, Topal ES, Aksulu BK, , Yaman B, Çiftçi IC, Bıyıklı T. (2015). Atletik Performans, Genetik ve Gen Dopingi. İstanbul Kanuni Sultan Süleyman Tıp Dergisi, 7(2):58-62.

16. Garatachea N, Verde Z, Santos-Lozano A, Yvert T, Rodriguez-Romo G, Sarasa FJ, HernándezSánchez S, Santiago C, Lucia A. (2014). ACTN3 R577X polymorphism and explosive leg-muscle power in elite basketball players. International Journal of Sports Physiology and Performance, 9(2), 226-232.

17. Sessa $F$, Chetta $M$, Petito $A$, Franzetti $M$, Bafunno V, Pisanelli D, Sarno M, luso S, Margaglione M. (2011). Gene Polymorphisms and Sport Attitude in Italian Athletes. Genetic Testing and Molecular Biomarkers, 15 (4), 285-290.

18. Günel $T$, Gümüşoğlu $E$, Hosseini $M K$, Yilmaz $Y E$, Dolekcap I, Aydinli K. (2014). Effect of angiotensin I-converting enzyme and $\alpha$-actinin-3 gene polymorphisms on sport performance. Molecular Medicine Reports, 9(4), 1422-1426.

19. Ulucan K, Sercan C, Biyikli T. (2015). Distribution of angiotensin-I converting enzyme insertion/ deletion and $\alpha$-actinin- 3 codon 577 polymorphisms in Turkish male soccer players. Genetics and Epigenetics, 7, 1-4.

20. Şanlısoy F, Altıntaş N, Büyükyazı G, Candan N. (2011). Ege bölgesi elit sporcularının ACTN3 R577X genotip dağılımının araştırılması. Cumhuriyet Medical Journal, 33(2), 153-159.

21. Yamak B, Yuce M, Bagci H, İmamoğlu O. (2015). Association between Sport Performance and AlphaActinin-3 Gene R577X Polymorphism. International Journal of Human Genetics, 15(1), 13-19.

22. Oh SD. (2007). The distribution of I/D polymorphism in the ACE gene among Korean male elite athletes. Journal of Sports Medicine and Physical Fitness, 47(2), 250-254. 